\title{
Iron, Copper and Zinc in Substitute Foods for Maternal Milk: Comparison with Infant Nutritional Requirements
}

\author{
Milena L. Moraes, ${ }^{a}$ Márcia B. S. Feijó, ${ }^{a}$ Fabiana M. Melo, ${ }^{a}$ \\ Reinaldo C. Campos ${ }^{*, a, b}$ and Rachel Ann Hauser- Davis ${ }^{b}$ \\ ${ }^{a}$ Departamento de Tecnologia de Alimentos, Escola de Nutrição, \\ Universidade Federal do Estado do Rio de Janeiro, Rua Xavier Sigaud, 290, \\ 20211-040 Rio de Janeiro-RJ, Brazil \\ ${ }^{b}$ Departamento de Química, Pontifícia Universidade Católica do Rio de Janeiro, \\ Rua Marquês de S. Vicente, 225, Gávea, 22453-900 Rio de Janeiro-RJ, Brazil
}

\begin{abstract}
Este estudo objetivou investigar os teores de ferro, cobre e zinco de fórmulas infantis para lactentes e leites em pó, disponíveis no mercado, realizando uma análise comparativa entre os teores encontrados, a ingestão diária recomendada (IDR) e a ingestão diária máxima tolerável (IDMT). A determinação dos elementos traço foi realizada por espectrofotometria de absorção atômica. Os teores de ferro, cobre e zinco variaram em uma ampla faixa, dependendo do produto, apresentando-se algumas vezes abaixo da IDR (ferro) e outras acima (zinco), ultrapassando o IDMT, o que compromete o uso confiável destes alimentos a longo prazo, principalmente em dietas monótonas.
\end{abstract}

This study aimed to investigate iron, copper and zinc contents in baby formulas for lactents and powdered milk, conducting a comparative analysis between the observed values, the dietary reference intake (DRI) and the tolerable upper intake level (UL). The determination of these trace elements was performed by atomic absorption spectrometry. Iron, copper and zinc values varied in a wide concentration range, depending on the product. They were sometimes below the DRI (iron) and sometimes above it (zinc), surpassing the UL, compromising the reliable use of these food products in the long run, especially in monotonous diets.

Keywords: trace elements, baby formulas for lactents, powdered milk, infant requirements, atomic spectrometry

\section{Introduction}

Exclusive maternal feeding until the child is six months old, and from then on, the inclusion of complementary foods in the child's diet available in the family unit is the procedure recommended by the World Health Organization (WHO) for children worldwide. ${ }^{1}$ This recommendation is based on the knowledge that, until the child is six months old, exclusive feeding on maternal milk is enough to satisfy the child's nutritional requirements, besides favoring protection against diseases. $^{2}$ After this age, the inclusion of complementary foods in the child's feeding schedule aims, mainly, to elevate energy and micronutrient quotas, maintaining breast feeding until the child is 12 or 24 months old. ${ }^{1-3}$

*e-mail: rccampos@puc-rio.br
There is evidence that weaning is intense and occurs very precociously. ${ }^{4}$ The introduction of complementary food ingestion happens very early in the child's life, and these foods are offered in insufficient quantities to reach nutritional requirements, especially micronutrient requirements. ${ }^{1}$ Studies point out that the early offer of milks and baby formulas for lactents are predictors of early weaning. ${ }^{2}$

Inadequate complementary food is a major cause of the high prevalence of malnutrition in the developing world. ${ }^{5}$ It is observed that, although greater intakes of complementary foods are associated with higher total energy intake, micronutrient intake remains low due to the low micronutrient concentration of these complementary foods. ${ }^{6}$

Minerals are micronutrients with an important role in childhood growth and development. ${ }^{7}$ Iron, copper and zinc are necessary in daily amounts much lower than $100 \mathrm{mg}$, 
although indispensable to the normal function of the human organism. ${ }^{8}$ Mineral deficiencies affect two-thirds of the world's population. ${ }^{8}$ This constitutes a serious public health problem, since it can cause damage to children's mental and psychomotor development, an increase in infant morbidity and mortality, a decrease in the individual's performance and apathy, along with a higher tendency towards infections. ${ }^{9}$

Iron deficiency anemia is the most common nutritional disorder in the world. ${ }^{8}$ However, iron deficiency anemia is not commonly encountered in lactents who were breast fed during the first six months, due to the high iron bioavailability in maternal milk and the bodily reserves of this mineral. ${ }^{2}$

Zinc deficiency can occur associated to insufficient intake or low bioavailability of this mineral in diets, having been observed in communities by various authors. ${ }^{10}$ Newborns do not possess zinc reserves, depending immediately, therefore, on the diet sources of this element. Furthermore, this mineral is much better absorbed when originating from human milk than from baby formulas. ${ }^{11}$ Zinc deficiency can harm growth and compromise the immune function, besides causing reversible hypogonadism. ${ }^{12}$ Excess zinc can cause nausea, vomiting, headaches and copper deficiencies. ${ }^{13}$

Copper deficiencies, as well as its toxicity, are also childhood concerns, even though they are less common. ${ }^{14}$ This trace element is involved in bone formation and resistance and childhood growth and development. ${ }^{14}$ Many feeding regimes provide lower amounts of recommended copper values. ${ }^{15}$ Copper deficiency can be observed in patients submitted to a zinc rich diet. ${ }^{7}$ When copper deficiency occurs, there are failures in collagen and elastin reticulation and problems with tissue plasticity and solidity, particularly in arteries. ${ }^{7}$ Its excess can cause diarrhea, nausea, vomiting, cirrhosis, anemia and bronchitis. ${ }^{13}$

However, even though many of these trace elements functions are well known, and even though good infant growth has been attained using milk formulas and powdered milk in infant feeding, there is not many data relative to the amounts of these elements in these products available in the Brazilian market, in order to compare them with infant nutritional requirements. Thus, the present study aims to determine iron, copper and zinc values in milk formulas and powdered milks available in the Brazilian market, evaluating their daily intake and comparing them with those recommended for lactents.

Atomic spectrometric methods are the most popular for the determination of trace metals in foods. This is certainly due to the convenient limits of detections that can be achieved, simplicity, availability and reasonable costs. Flame atomic absorption spectrometry (F AAS) is a natural choice if there are not too many elements to be determined, since it is still a monoelemental method. Graphite furnace atomic absorption spectrometry (GF AAS) can be used instead, if lower limits of detection are necessary. ${ }^{16}$ Chemical vapor generation atomic absorption spectrometry may also be a choice for those elements that are able to form volatile species, such as As and Se, in the hydride generation technique. However, in those cases where a large number of elements are to be determined, multielemental techniques, such as inductively coupled plasma optical emission spectrometry (ICP-OES) ${ }^{17}$ or inductively coupled plasma mass spectrometry (ICP-MS) ${ }^{18}$ are preferred, if available. In the present study, F AAS and GF AAS were the techniques of choice, since three elements were investigated.

Regarding sample preparation, many procedures are available. They encompass dry ashing, wet ashing in open or closed systems at high pressure, as well as conventional or microwave-assisted heating. Different acids or acid mixtures can be used, assisted or not by further addition of oxidizing agents. A recent detailed review on sample preparation methods for food analysis by spectroanalytical methods was published..$^{19}$ Direct solid sampling is also an alternative, especially in the case of GF AAS..$^{20}$ Due to the very low concentrations to be determined, sample preparation can be the most risky analysis step in relation to contamination and losses. In this sense, closed systems are recommended and, in this case, vapor phase digestion is an alternative for decreasing blanks. ${ }^{21}$ An interesting alternative is the use of one vessel systems: the whole sample preparation is performed in the same vessel where the sample was first weighed. ${ }^{22-24}$

\section{Experimental}

For the present study, the following products were selected: infant formula for lactents up to six months old (FIL 1), infant formula for lactents over six months old (FIL 2), whole bovine powdered milk and whole caprine powdered milk. FIL1 and FIL2 are defined as products that satisfy the nutritional requirements of their respective age groups. ${ }^{25}$ Samples were acquired at the local market, in Rio de Janeiro City, and are all commercial products. The appearance of the products was as follows: cans of $450 \mathrm{~g}$ (FIL 1 and FIL 2), $400 \mathrm{~g}$ (bovine powdered milk) and box of $200 \mathrm{~g}$ (caprine powdered milk). Two units of each product were selected, from the same manufacturing lot.

The content of each container was manually homogenized, by agitation, and three aliquots were taken from each product. Sample digestion ${ }^{26,27}$ was performed in $50 \mathrm{~mL}$ graduated polyethylene tubes, with conical bottoms and 
screw-on lids, containing $2 \mathrm{~g}$ of the whole sample accurately weighed. A volume of $8.0 \mathrm{~mL}$ of $1: 1(\mathrm{v} / \mathrm{v}) \mathrm{H}_{2} \mathrm{SO}_{4}: \mathrm{HNO}_{3}$ mixture were added to the samples, first allowing contact with the sample for $24 \mathrm{~h}$, at room temperature, with the lid not completely screwed-on. Following this, another $4 \mathrm{~mL}$ of the acid mixture were added. The tubes were then taken to a heating plate, at $80^{\circ} \mathrm{C}$, for $2 \mathrm{~h}$. After cooling, $3 \mathrm{~mL}$ of $30 \%(\mathrm{~m} / \mathrm{v})$ hydrogen peroxide were added, and the mixture was left to react during $10 \mathrm{~min}$, followed by the addition of another $1 \mathrm{~mL}$ of perhydrol. This mixture was heated on a heating plate at $80{ }^{\circ} \mathrm{C}$ for another hour, until total dissolution was observed. The tubes were then diluted up to $20 \mathrm{~mL}$ with ultrapure water, homogenized, and left at rest. In some cases, if periods higher than $48 \mathrm{~h}$ between the digestion and the analysis by atomic absorption occurred, a supernatant residue formation was observed, which was discarded by centrifugation (15 min), immediately before the instrumental analysis, transferring the yellowish solution to another polyethylene container. All glass and plasticware were previously decontaminated by immersion in $20 \%(\mathrm{v} / \mathrm{v}) \mathrm{HNO}_{3}$ for at least $24 \mathrm{~h}$. All reagents utilized were of analytical grade, and the water was decontaminated by an ultra purification system.

Iron and zinc measurements were performed in a Varian model AA5 atomic absorption spectrophotometer, with flame atomization, while copper was determined in a Perkin Elmer model AA 1100 atomic absorption spectrophotometer, equipped with an HGA 300 graphite atomizer (longitudinal heating, continuous background correction) and an AS 40 auto-sampler. Hollow cathode lamps were used as line sources operated at 324.7, 248.3 and $213.9 \mathrm{~nm}$, for copper, iron and zinc respectively. External calibration was performed with aqueous analytical solutions, prepared using $1000 \mathrm{mg} \mathrm{L}^{-1}$ Titrisol standard solutions, adequately diluted with $0.2 \%(\mathrm{v} / \mathrm{v}) \mathrm{HNO}_{3}$. The adequacy of this calibration procedure was confirmed by comparing the slopes of the external calibration curves with those of analyte addition curves for the investigated different samples, where no statistically significant difference was observed. ${ }^{28}$ The instrumental parameters were adjusted according to the manufacturers' recommendations and the graphite furnace temperature program (see Table 1) was optimized by pyrolysis and atomization temperature curves. All the results are the average of at least three measurements. The flame readings were taken in maximum absorbance (height), while the graphite furnace measurements were taken in integrated absorbance (area), in consonance with the stabilized platform temperature furnace (STPF) concept. ${ }^{29}$ Eventually, a sample dilution was necessary, to adjust the reading to the calibration curve interval, taking care to use the sample blank for dilution. The curve parameters were estimated by simple linear regression, calculating the concentrations of the samples from there.

Table 1. Copper graphite furnace temperature program

\begin{tabular}{lccc}
\hline Step & $\mathrm{T} /{ }^{\circ} \mathrm{C}$ & Slope / & Hold time / s \\
\hline 1 & 90 & 5 & 10 \\
2 & 120 & 5 & 10 \\
3 & 1000 & 10 & 30 \\
4 & 20 & 1 & 5 \\
5 & 2300 & 0 & 5 \\
6 & 2650 & 1 & 3 \\
7 & 20 & 1 & 5 \\
\hline
\end{tabular}

For comparison purposes, the masses of the studied elements in one serving of each product were calculated, whose preparation was conducted according to the manufacturers recommendations. This serving corresponds to the gastric capacity of a child, which varies throughout development, and was, in the present study, considered as the period between 0 and 11 months.

The amounts of the elements discussed in this study in these servings were compared to the dietary reference intake (DRI) and to the tolerable upper intake level (UL), but only for iron and zinc, since an established UL value for copper has still has not been determined. ${ }^{30}$

According to Cameron and Hofvander ${ }^{31}$ the gastric capacity corresponds to 25 to $30 \mathrm{~mL} \mathrm{~kg}^{-1}$ meal. In the present study, the gastric capacity considered as a reference value was of $30 \mathrm{~mL} \mathrm{~kg}^{-1}$ and all the results were rounded up to multiples of 10 that do not surpass the equivalent value to the gastric capacity. The weight used in the gastric capacity calculations was the mean weight (P50) found at the weight/age index table for boys from 0 to 11 months, developed by the National Center for Health Statistics ${ }^{32}$ (see Table 2). The male sex was chosen due to the fact that the requirements between sexes are different, and are usually higher for males.

\section{Results and Discussion}

The accuracy of the procedure was evaluated by the analysis of a certified reference material (NIST 1549, NonFat Milk Powder). The results are displayed in Table 3, and good agreement can be observed between found and certified values.

Table 4 shows the average and standard deviation of copper, iron and zinc concentrations in the powdered milk and baby formulas analyzed in this study. 
Table 2. Amount of infant formulas for lactents and powdered milk used per serving per age

\begin{tabular}{|c|c|c|c|c|c|c|}
\hline \multirow[b]{2}{*}{ Age / month } & \multirow[b]{2}{*}{$\begin{array}{l}\text { Infant mean } \\
\text { weight }{ }^{20} / \mathrm{kg}\end{array}$} & \multirow[b]{2}{*}{ Gastric capacity / mL } & \multicolumn{4}{|c|}{ Amount / g } \\
\hline & & & FIL 1 & FIL 2 & $\begin{array}{c}\text { Bovine } \\
\text { powdered milk }\end{array}$ & $\begin{array}{c}\text { Caprine } \\
\text { powdered milk }\end{array}$ \\
\hline 0 & 3.3 & 90 & 12.0 & 12.7 & 11.7 & 10.8 \\
\hline 1 & 4.3 & 120 & 16.0 & 16.9 & 15.6 & 14.4 \\
\hline 2 & 5.2 & 150 & 20.0 & 21.2 & 19.5 & 18.0 \\
\hline 3 & 6.0 & 180 & 23.9 & 25.4 & 23.4 & 21.6 \\
\hline 4 & 6.7 & 200 & 26.6 & 28.2 & 26.0 & 25.2 \\
\hline 5 & 7.3 & 210 & 27.9 & 29.6 & 27.3 & 25.2 \\
\hline 6 & 7.8 & 230 & 30.6 & 32.4 & 29.9 & 27.6 \\
\hline 7 & 8.3 & 240 & 31.9 & 33.8 & 31.2 & 28.8 \\
\hline 8 & 8.8 & 260 & 34.6 & 36.7 & 33.8 & 31.2 \\
\hline 9 & 9.2 & 270 & 35.9 & 38.1 & 35.1 & 32.4 \\
\hline 10 & 9.5 & 280 & 37.2 & 39.5 & 36.4 & 33.6 \\
\hline 11 & 9.9 & 290 & 38.6 & 40.9 & 37.7 & 34.8 \\
\hline
\end{tabular}

Table 3. Determination of $\mathrm{Cu}, \mathrm{Fe}$ and $\mathrm{Zn}\left(\mu \mathrm{g} \mathrm{g}^{-1}\right)$ in NIST $1547 \mathrm{Non}$ Fat Milk Powder certified reference material; certified values in comparison to those found using the proposed procedure (mean \pm standard deviation, $\mathrm{n}=3$ )

\begin{tabular}{lccc}
\hline & \multicolumn{3}{c}{ Elements } \\
& $\mathrm{Cu}$ & $\mathrm{Fe}$ & $\mathrm{Zn}$ \\
\hline Found & $0.66 \pm 0.01$ & $1.76 \pm 0.03$ & $48.6 \pm 0.1$ \\
Certified & $0.7 \pm 0.1$ & $1.78 \pm 0.10$ & $46.1 \pm 2.2$ \\
\hline
\end{tabular}

Figures 1, 2 and 3 show the masses of copper, iron and zinc present in the preparation servings, as defined previously in this study, comparing them with the DRI and UL, respectively.

Iron is an element with a minimum nutritional requirement until the child is six months old $(0.27 \mathrm{mg}$ per day). ${ }^{30}$ This occurs because in the first two months, a marked decline in hemoglobin plasmatic levels occurs, with a consequent increase in iron availability, which will be reused to attend metabolic needs, new hemoglobin synthesis and loss replenishing, reducing the need for exogenous iron and transforming anemia into a less frequent deficiency in the first 4 months. ${ }^{33}$ There is a slight variation in bodily iron from birth to the fourth month of the child's life, with a marked increase at 12 months, justifying the elevated risk of iron deficiency in the second semester ${ }^{34}$ and an increase in iron requirements, which goes up to $11 \mathrm{mg}$ per day. ${ }^{30}$

FIL1 can be used to reach iron requirements until the lactent is six months old (which is the product's target public) using one serving. However, FIL2 only offers $14 \%$ to $18 \%$ of iron DRI per serving in the second semester. With these iron values, an offer of approximately 7 to 6 servings from the $6^{\text {th }}$ to $11^{\text {th }}$ month would be necessary to reach the DRI. According to the WHO, ${ }^{1}$ from the $6^{\text {th }}$ month onwards the child should not only be breast-fed but should also receive other food sources besides maternal milk. However, an intense collaboration of FIL 2 in this complementary feeding increases the risk of iron deficiency, because it would be unfeasible to offer the necessary daily servings to reach that value. So, FIL2 is an inadequate food source regarding iron values, since it is classified as a product made to satisfy the nutritional needs of its respective age group. ${ }^{25}$ The mineral

Table 4. Concentrations of iron, copper and zinc in the studied samples (mean \pm standard deviation, $n=3$ )

\begin{tabular}{lcccccc}
\hline & \multicolumn{2}{c}{$\mathrm{Fe}$} & \multicolumn{2}{c}{$\mathrm{Cu}$} & \multicolumn{2}{c}{$\mathrm{Zn}$} \\
Samples & $\mathrm{mg}$ per $100 \mathrm{~g}$ & $\mathrm{mg} \mathrm{L}-1(\mathrm{a})$ & $\mathrm{mg}$ per $100 \mathrm{~g}$ & $\mathrm{mg} \mathrm{L}^{-1(\mathrm{a})}$ & $\mathrm{mg} \mathrm{per} \mathrm{100} \mathrm{g}$ & $\mathrm{mg} \mathrm{L}$ \\
\hline FIL 1 & $3.97 \pm 0.15$ & $5.28 \pm 0.20$ & $0.45 \pm 0.04$ & $0.60 \pm 0.05$ & $9.01 \pm 0.51$ & $11.98 \pm 0.68$ \\
FIL 2 & $4.83 \pm 0.21$ & $6.81 \pm 0.30$ & $1.04 \pm 0.16$ & $1.47 \pm 0.23$ & $13.58 \pm 1.57$ & $19.15 \pm 2.21$ \\
Bovine powdered milk & $0.02 \pm 0.02$ & $0.03 \pm 0.03$ & $0.11 \pm 0.02$ & $0.14 \pm 0.03$ & $6.28 \pm 0.55$ & $8.16 \pm 0.72$ \\
Caprine powdered milk & $6.08 \pm 0.16$ & $7.30 \pm 0.19$ & $0.14 \pm 0.03$ & $0.17 \pm 0.04$ & $6.24 \pm 0.14$ & $7.49 \pm 0.17$ \\
Human milk & - & $0.30 \pm 0.10$ & - & $0.25 \pm 0.03$ & - & $1.20 \pm 0.20$ \\
\hline
\end{tabular}

${ }^{\mathrm{a} M i l k}$ reconstituted with water as recommended by the manufacturer. ${ }^{\mathrm{b}}$ According to WHO, $1998 .{ }^{1}$ 


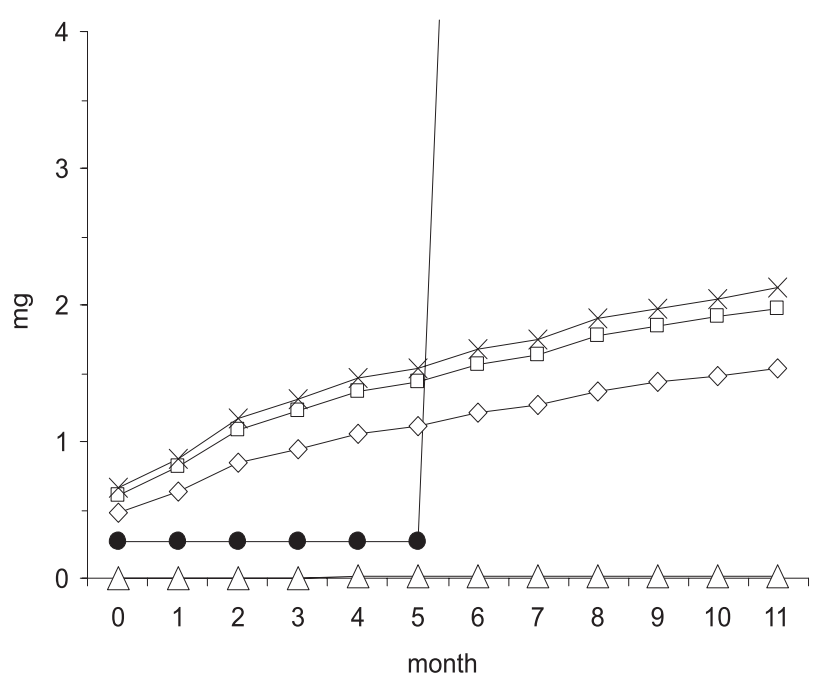

Figure 1. Dietary reference intake $(\bullet)$, tolerable upper intake level $(O)$ of Fe for children from 0 to 11 months old compared with the supply of Fe per serving given by FIL $1(\diamond)$, FIL $2(\square)$, bovine powdered milk $(\triangle)$ and caprine powdered milk $(\mathrm{x})$.

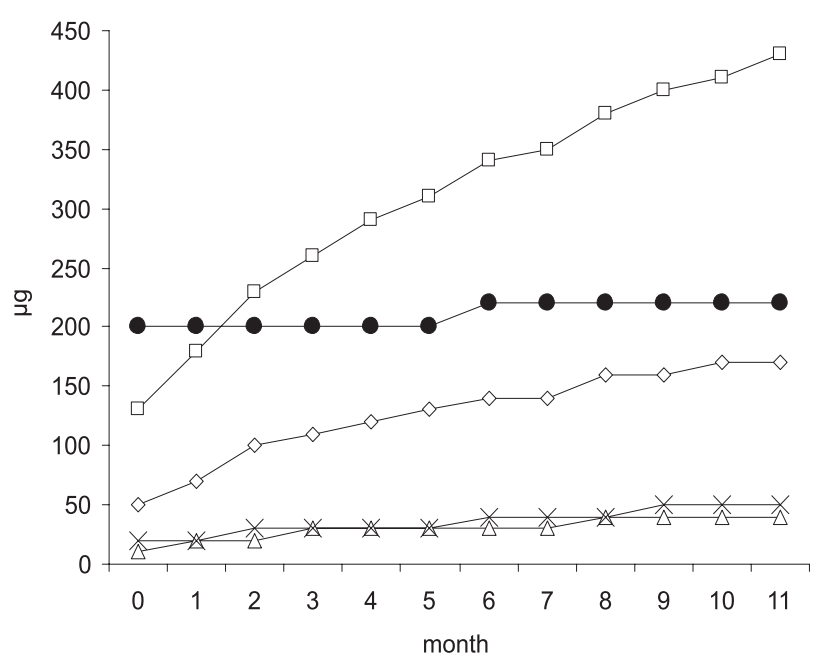

Figure 2. Dietary reference intake $(\bullet)$ of $\mathrm{Cu}$ for children from 0 to 11 months old compared with the supply of $\mathrm{Cu}$ per serving given by FIL $1(\diamond)$, FIL $2(\square)$, bovine powdered milk $(\triangle)$ and caprine powdered milk (x).

composition of infant formula is based, primarily, on the mineral content of human milk, as well as on intra-uterine accretion. ${ }^{35}$ In some cases, the specific nutrient levels of infant formula exceed the levels found in human milk. For example, the iron content in infant formula is increased to address iron deficiency anemia. In general, the iron present in human milk is more bioavailable than that present in infant formula. It is for this reason that the iron content of fortified infant formula $\left(5-12 \mathrm{mg} \mathrm{L}^{-1}\right)$ is $12-22$ times higher than that of human milk (0.3-0.5 $\left.\mathrm{mg} \mathrm{L}^{-1}\right)$. In Europe, infant formula contain approximately $5-8 \mathrm{mg} \mathrm{L}^{-1}$ iron, similar amount to that found in our study, while in other locations (including the United States) the iron content is approximately $12 \mathrm{mg} \mathrm{L}^{-1}$ iron. ${ }^{35}$ Although iron fortification

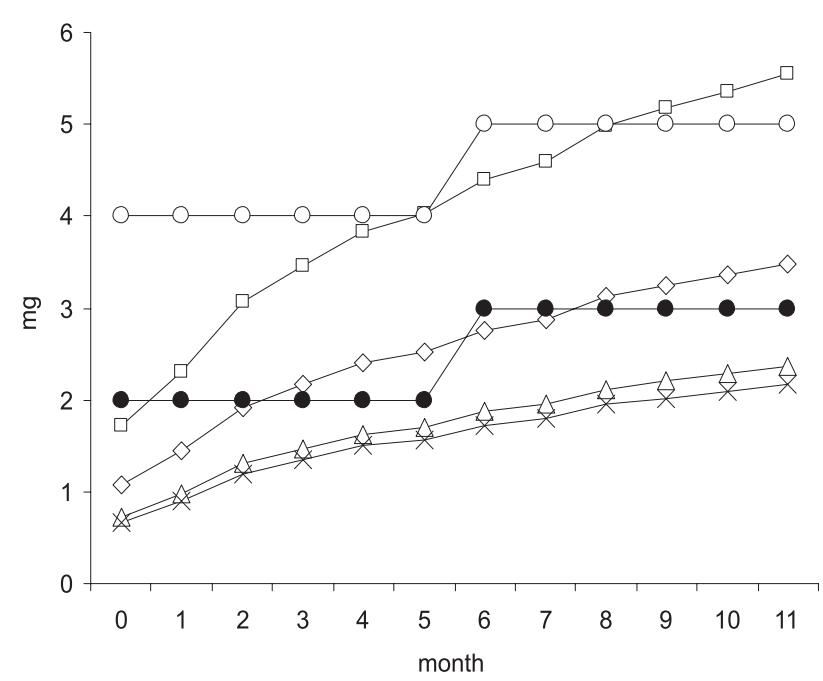

Figure 3. Dietary reference intake $(\bullet)$, tolerable upper intake level $(\bigcirc)$ of $\mathrm{Zn}$ for children from 0 to 11 months old compared with the supply of Zn per serving given by FIL $1(\diamond)$, FIL $2(\square)$, bovine powdered milk $(\triangle)$ and caprine powdered milk $(\mathrm{x})$.

of infant formula lead to a reduction in the prevalence of anemia, the level of fortification and the type of iron salt with which to supplement are continually being evaluated. Iron salts differ in bioavailability as well as their pro-oxidant properties. ${ }^{36,37}$ In general, infant formulas are supplemented with iron as ferrous sulfate or ferrous gluconate. Although ferrous sulfate demonstrates acceptable bioavailability, it has lower reduction potential than ferric glycinate, ferrous fumarate or ferrous succinate. ${ }^{35}$ The infant formulas that we have studied contained no information on the type of iron used in supplementation.

Bovine powdered milk presented the lowest iron values, below the limit of detection, also demonstrating inadequacy regarding this element intake. The product label informed that the quantities of iron were insignificant. Although it is observed that the absorption of iron in human milk is around $49 \%$, the absorption value in bovine milk is of $1 \% .^{11}$ Finally, caprine powdered milk, although presenting iron values higher than the DRI until the $5^{\text {th }}$ month, from then on presented only $15 \%$ to $19 \%$ of the DRI in the second semester, thus making it necessary to offer approximately 7 to 5 daily servings of caprine powdered milk from the $6^{\text {th }}$ to $11^{\text {th }}$ month, to reach the DRI, which also categorizes this product as a poor food source regarding this element. Evidently, due to its low values, there is no chance of surpassing the iron UL using any of the analyzed products. ${ }^{30}$ It seems that iron bioavailability is higher in caprine milk than in bovine milk ${ }^{38}$ due to higher nucleotide content, contributing to better absorption in the gut. ${ }^{39,40}$

Copper DRI is of $0.20 \mathrm{mg}$ for lactents of 0 to 6 months old, and, from then on, of $0.22 \mathrm{mg}$ for children under 1 year old. ${ }^{30}$ FIL 1 possesses considerable copper amounts, with 
each serving corresponding to $25 \%$ of the DRI in month $0,35 \%$ in the $1^{\text {st }}$ month, $50 \%$ in the $2^{\text {nd }}$ month, $55 \%$ in the $3^{\text {rd }}$ month, $60 \%$ in the $4^{\text {th }}$ month and $65 \%$ in the $5^{\text {th }}$ month. So, if a lactent under 6 months old feeds exclusively on this product (which guarantees, according to the Codex Alimentarius, ${ }^{25}$ to satisfy the child's requirements), he or she would obtain a copper supply above the DRI, considering that the number of servings consumed per day is always higher than four. However, as a UL is not yet established for this age group, it is not possible to conjecture on an ingestion much higher that the DRI. Copper content in infant formulas attempts similarity to the content of human milk. ${ }^{33}$ Sola-Larrañaga and Navarro-Blasco ${ }^{41}$ determined copper in 35 infant formulas for infants of up to six months old, in Spain. For this element, they found mean and standard deviations of 0.57 and 0.14 , respectively, similar to the values found in the present study. FIL 2 presents even higher copper values, with one serving representing $65 \%$ of the DRI in month $0,90 \%$ in the $1^{\text {st }}$ month, $115 \%$ in the $2^{\text {nd }}$ month, $130 \%$ in the $3^{\text {rd }}$ month, $145 \%$ in the $4^{\text {th }}$ month, $155 \%$ in the $5^{\text {th }}$ and $6^{\text {th }}$ month, $160 \%$ in the $7^{\text {th }}$ month, $170 \%$ in the 8 th month, $180 \%$ in the $9^{\text {th }}$ month, $190 \%$ in the $10^{\text {th }}$ month and $200 \%$ in the $11^{\text {th }}$ month. In bovine powdered milk, copper is found at its lowest values, which would not allow an individual under 6 months old, feeding exclusively on this product, to reach the DRI of this element (5\% of the DRI in month zero, $10 \%$ in the $1^{\text {rst }}$ and $2^{\text {nd }}$ months and $15 \%$ from the $3^{\text {rd }}$ to $5^{\text {th }}$ month), since offers of approximately 20 to 7 servings per day would be necessary, from months 0 to 5 , respectively, to reach the DRI. Regarding lactents 6 months old and older, the copper supply per serving is of $14 \%$ of the DRI in the $6^{\text {th }}$ and $7^{\text {th }}$ months and $18 \%$ from the $8^{\text {th }}$ to $11^{\text {th }}$ month, indicating that complementary feeding in this age group should not only be based on this food product, regarding copper. ${ }^{1}$ Caprine powdered milk also presented low copper values, which would not reach the requirements of a lactent under six months old, feeding exclusively on this product, because it presented $10 \%$ of the DRI in one serving from month 0 to the $1^{\text {st }}$ month, and $15 \%$ from the $2^{\text {nd }}$ to $5^{\text {th }}$ month. For lactents over 6 months old the supply is of $18 \%$ of the DRI, in one serving, from the $6^{\text {th }}$ to $8^{\text {th }}$ month and of $23 \%$ from the $9^{\text {th }}$ to $11^{\text {th }}$ month.

The zinc DRI during the first semester is of $2 \mathrm{mg}$, and in the second semester this value increases to $3 \mathrm{mg}{ }^{2}$ The $\mathrm{UL}$ for this element is of $4 \mathrm{mg}$ during the first semester, and in the second semester increases to $5 \mathrm{mg} .{ }^{2}$ One serving of FIL1 offers, in month $0,27 \%$ of the UL; $36 \%$ in the $1^{\text {st }}$ month, $48 \%$ in the $2^{\text {nd }}$ month, $54 \%$ in the $3^{\text {rd }}$ month, $60 \%$ in the $4^{\text {th }}$ month and $63 \%$ in the $5^{\text {th }}$ month. This means that the zinc values observed in FIL1 were high and would put a lactent under six months old, feeding exclusively on this product, at toxicity risk. FIL 2, from all the analyzed products, was the one that presented the higher $\mathrm{Zn}$ values, surpassing, per serving, the UL values in the $5^{\text {th }}$ month (101\%), $9^{\text {th }}$ month $(104 \%), 10^{\text {th }}$ month $(107 \%)$ and $11^{\text {th }}$ month $(111 \%)$, and putting the lactent consumers of this food product also at toxicity risk, in case of the ingestion of more than one serving per day. In a recent in vitro study, performed at newborn gastric $\mathrm{pH}$, it was concluded that zinc bioavailability from breast milk samples was higher than that associated to infant formulas. ${ }^{42}$

Bovine powdered milk, although containing lower values than baby formulas for lactents, also presented high values, with which lactents under six months old, exclusively feeding on this product, would reach UL. This milk presented $18 \%$ of the UL in one serving in month 0 , $24 \%$ in the $1^{\text {st }}$ month, $33 \%$ in the $2^{\text {nd }}$ month, $37 \%$ in the $3^{\text {rd }}$ month, $41 \%$ in the $4^{\text {rth }}$ month and $43 \%$ of the UL in the $5^{\text {th }}$ month, meaning that lactents consuming 4 daily servings of this food product are at toxicity risk. From the $6^{\text {th }}$ month onward the zinc supply continued to be elevated, between $37 \%$ and $47 \%$, from the $6^{\text {th }}$ to $11^{\text {th }}$ month, respectively. Caprine powdered milk presented values similar to bovine powdered milk, also presenting toxicity risks to lactents feeding exclusively on this product. Caprine powdered milk presented $17 \%$ of the UL in one serving from month $0,22 \%$ in the $1^{\text {st }}$ month, $30 \%$ in the $2^{\text {nd }}$ month, $34 \%$ in the $3^{\text {rd }}$ month, $37 \%$ in the $4^{\text {th }}$ month, and $39 \%$ of the UL in the $5^{\text {th }}$ month, which means that lactents consuming 5 daily servings of this product from the $1^{\text {st }}$ month onwards are also at toxicity risk. From the $6^{\text {th }}$ month onwards the zinc supply continued elevated, between $34 \%$ and $43 \%$ from the $6^{\text {th }}$ to $11^{\text {th }}$ month, respectively. However, the fact that zinc bioavailability was found to be higher in human milk when compared to caprine and bovine milk must be considered. ${ }^{38}$

\section{Conclusions}

Unquestionably, maternal milk is the ideal food product from a nutritional point of view for child feeding, since its composition is specific to attend our species requirements. ${ }^{1,2}$ Previous studies have demonstrated that iron, copper and zinc concentrations of human milk are independent of the mother's mineral status, ${ }^{1}$ with mineral transportation conducted by proteins through the mammary gland epithelial tissue, insuring, in this way, an adequate supply of iron, copper and zinc in maternal milk. ${ }^{14}$

The accuracy of the analytical procedure was assured by the good agreement between found and certified values in the analysis of a certified reference material. Sample preparation was simple, efficient and the relatively long analysis time can be compensated by the possibility of 
using very large batches, if necessary. The procedure was performed in only one vessel, minimizing the risks of contamination. Regarding the analyzed products, it was observed that the iron intake from these products is usually low, which could lead to iron deficiency, and, consequently, to iron deficiency anemia in the second semester, if the diet offered to the lactent does not include other iron sources. Copper supply was low in the powdered milks (especially until 6 months old) and excessive in the baby formulas for lactents (from 0 to 11 months). Zinc was the element that showed concern in the long term use of these products, since zinc values were high in all products.

The findings of the present work are in contrast with those of Melø et al. ${ }^{43}$ who presented, as a general conclusion, the idea that a diet based solely on industrialized prepared food products provides a sufficient intake of minerals and trace elements. These authors did not consider the gastric capacity of the infants, the caloric density of the diet, and only six months old infants were considered. Moreover, the infant formulae can present different mineral contents form place to place, and, indeed, their levels for Fe and $\mathrm{Zn}$ were significantly different from those found in the present study.

It is necessary to dedicate more attention to diets and products dedicated to lactents, both in the first semester, when many receive only artificial feeding with these products, and the second semester, where monotonous diets can compromise the available amount of minerals, both by deficiency or excess, where both have consequences to childhood health. Bioavailability of these elements in the studied products would increase the concerns in the cases of deficiencies. Regional differences in the trace elements composition of these products must also be considered. ${ }^{43}$

\section{Acknowledgments}

The authors are thankful to the Brazilian National Research Council - CNPq - for the financial support.

\section{References}

1. World Health Organization (WHO); Complementary Feeding of Young Children in Developing Countries: A Review of Current Scientific Knowledge, World Health Organization: Geneva, 1998.

2. World Health Organization (WHO); Nutrient Adequacy of Exclusive Breastfeeding for the Term Infant During the First Six Months of Life, World Health Organization: Geneva, 2002.

3. World Health Organization (WHO); Complementary Feeding: Family Foods for Breastfeeding Children, World Health Organization: Geneva, 2000.
4. Ryan, A. S.; Zhou, W.; Arensberg, M. B.; Womens Health Issues 2006, 16, 243.

5. Michaelsen, K. F.; Friis, H.; Nutrition 1998, 14, 763.

6. Kimmons, J. E.; Dewey, K. G.; Haque, E.; Chakraborty, J.; Osendarp, S. J. M.; Brown, K. H. J.; Nutrition 2005, 135,444.

7. Rowin, J.; Lewis, S. L.; JNNP 2005, 76, 750.

8. http://www.who.int/nut/ida.htm, accessed in July 2007.

9. Walker, S. P.; Wachs, T. D.; Gardner, J. M.; Lozoff, B.; Wasserman, G. A.; Pollitt, E.; Carter, J. A.; Lancet 2007, $369,145$.

10. Buzina, R.; Jusíc, M.; Sapunar, J.; Milanovíc, N.; Am. J. Clin. Nutr. 1980, 33, 262.

11. Mahan, L. K.; Escott-Stump, S.; Krause: Alimentos, Nutrição

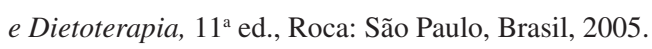

12. Scheplyagina, L. A.; J. Trace Elem. Med. Biol. 2005, 19, 29.

13. Waitzberg, D. L.; Nutrição Oral, Enteral e Parenteral na Prática Clínica, $3^{\mathrm{a}}$ ed., Atheneu: São Paulo, Brasil, 2002.

14. Domellof, M.; Lonnerdal, B.; Dewey, K. G.; Cohen, R. J.; Hernell, O.; Am. J. Clin. Nutr. 2004, 79, 111.

15. Hotz, C.; Lowe, M. N.; Araya, M.; Brown, K. H.; J. Nutr. 2003, 133, 1563.

16. Saracoglu, S.; Saygi, K. O.; Uluozlu, O. D.; Tuzen, M.; Soylak, M.; Food Chem. 2007, 105, 280.

17. Ikem, A.; Nwankwoala, A.; Odueyungbo, S.; Nyavor, K.; Egiebor, N.; Food Chem. 2002, 77, 439.

18. Cubadda, F.; J. AOAC Int. 2004, 87, 173.

19. Korn, M. G. A; Morte, E. S. B.; Santos, D. C. M. B.; Castro, J. T.; Barbosa, J. T. P.; Teixeira, A. P.; Fernandes, A. P.; Welz, B.; Santos, W. P. C.; Santos, E. B.G. N.; Korn, M.; Appl. Spectrosc. Rev. 2008, 43, 67.

20. Vale, M. G. R.; Oleszczuk, N.; Santos, W. N. L.; Appl. Spectrosc. Rev. 2006, 41, 377.

21. Araújo, G. C. L.; Nogueira, A. R. A.; Nóbrega, J. A.; Microchim. Acta 2004, 144, 81.

22. Silva, W. G. P.; Campos, R. C.; Miekeley, N.; Anal. Lett. 1998, $31,1061$.

23. Anderson, K. A.; At. Spectrosc. 1996, 17, 30.

24. Dhindsa, H. S.; Battle, A. R.; Mierzwa, J.; J. Anal. Chem. 1998, $362,74$.

25. Codex Alimentarius, Codex Standard for Infant Formula; Codex Stan 72, 1981.

26. Association of Official Analytical Chemists (AOAC); Official Methods of Analysis, 14 ${ }^{\text {th }}$ ed., AOAC: Virginia, 1984.

27. James, C. S.; Analytical Chemistry of Foods, Chapman \& Hall: London, 1995.

28. Calcutt, R.; Boyd, R.; Statistics for Analytical Chemists, Chapman and Hall: London, 1983.

29. Welz, B.; Sperling, M.; Atomic Absorption Spectrometry, $3^{\text {rd }}$ ed., VCH-Wiley: Weinheim, 1999.

30. Institute of Medicine (IOM); Dietary Reference Intakes for Vitamin A, Vitamin K, Arsenic, Boron, Chromium, Copper, 
Iodine, Iron, Manganese, Molybdenum, Nickel, Silicon, Vanadium, and Zinc. Food and Nutrition Board, National Academy Press: Washington, DC, 2002.

31. Cameron, M.; Hofvander, Y.; Manual on Feeding Infants and Young Children, Oxford Medical Publication: New York, 1983.

32. http://www.cdc.gov.growthcharts, accessed in May 2007.

33. Lonnerdal, B.; Dewey, K. G.; Nestlé Nutrition Services-Anais Nestlé, 1996, 52, 11.

34. Davi, N.; Oski, F. A. In Iron Deficiency and Related Nutritional Anemia; Dallman, P. R.; Yip, R.; OskI, F. A., eds.; WB Saunders: Philadelphia, 1993.

35. Kaup, S. M.; Int. Dairy J. 1998, 8, 435.

36. Clemens, R. A.; Mercurio, K. C.; J. Food Sci. 1981, 46, 930.

37. Theuer, R. C.; Martin, W. H.; Wallander, J. F.; Sarett, H. P.; J. Agric. Food Chem. 1973, 21, 482.
38. Shen, L.; Robberecht, H.; Van Dael, P.; Deelstra, H.; Biol. Trace Elem. Res. 1995, 49, 107.

39. Schlimme, E.; Martin, D.; Meisel, H.; Br. J. Nutr. 2000, 38, S59.

40. Mc Cullough, E. S. W.; Br. Food J. 2003, 105, 239.

41. Sola-Larrañaga, C.; Navarro-Blasco, I.; Food Chem. 2009, 112 , 198.

42. Bermejo, P.; Peña, E. M.; Domínguez, R.; Bermejo, A.; Cocho, J. A.; Fraga, J. M.; Food Chem. 2002, 77, 361.

43. Melø, R.; Gellein, K.; Evje, L.; Syversen, T.; Food Chem. Toxicol. 2008, 46, 3339.

Received: June 24, 2008

Web Release Date: September 25, 2009 